or for the experimental worker newly entering the field. It provides a rigorous quantum-mechanical treatment throughout, and although physical arguments are introduced where they are relevant, the treatment is everywhere quantitative, using the most appropriate mathematical methods. To read the book properly the reader must be prepared for strenuous work.

While summarizing the main experimental tech. niques the author does not pretend to treat them thoroughly. Nor will the chemist find that the book abounds with examples of high-resolution spectra and their detailed interpretation. The emphasis at all times is, as the title implies, on the theoretical principles, their development and their relevance to typical experimental situations. While some readers might like to see more space in such a book devoted to this subject and less to that, a matter on which agreement is not to be expected, it can certainly be said that no important topic is omitted. After a general introduction, successive chapters deal with the motion of free spins, macroscopic aspects and experimental methods, dipolar broadening, spin temperature, electron-nucleus interactions, quadrupole interactions, thermal relaxation, dynamic polarization, motional effects, high-resolution spectra and the effects of strong radio-frequency fields. There are few tables of experimental data and no exhaustive lists of references.

Summarizing, this is an excellent and important book which no worker in the field and no library can afford not to have.

E. R. ANDREW

\section{SWITCHING TECHNIQUES}

\section{Static Relays for Electronic Circuits}

Edited by Richard F. Blake. (Based on the Static Relays Symposium sponsored by Electronics Components Research Department, U.S. Army Signal Research and Development Laboratory.) Pp. viii + 198. (Elizabeth, N.J.: Engineering Publishers. Distributed by Reinhold Publishing Corporation, Now York; and Chapman and Hall, Ltd., London.) 63s. net.

HIS book is basically a collection of eightoon articles on switching techniques which are being used, or which with development may be capable of being used, to approximate the function of the electromechanical relay. Contributions have been made by specialists from thirteen American firms and research organizations.

The 'static relay concept' is introduced by the editor in the first chapter. Briefly, this concept is that of a device which has no moving parts, provides electrical isolation between control and contact circuits, and also discrete 'on' and 'off' states in the contact circuits. The suggestion made is not that the electromechanical relay is likely to become obsolescent, but that the possible speed of operation, reliability, ruggedness, long lifeand freedom from 'bounce' of the static device will have great advantagos in certain applications. A comprehensive list of further specifications and standards, which have been found useful in the development stage, is elaborated in Chapter 3. The next two chapters describe in detail the realization of two types of static relay. In the first type the input signal controls a transistor oscillator, the output of which is taken through a transformer (to provide electrical isolation) and rectified to switch a further transistor used as the 'contact'. This principle is capable of many variations and the author describes further possibilities. The second type achieves electrical separation by an optical link, using a small lamp operated by the input signal and a photovoltaic: cell to switch the contact transistor(s).

From this point onward only two of the chapters deal strictly with the realization of the static relay concept as stated, but with various switching circuits which have relay-like behaviour and with devices which may be used in such circuits. The exceptions are Chapter 8, in which the oscillator-controlled switch again receives attention, and Chapter 17 , in which a transistor sampling relay is described. Other chapters deal with the use of magnetic ampli fiers, transistors, diodes, $p-n-p-n$ devices, tunnel diodes and photosensitive devices in switching circuits.

The book suffers from a certain amount of repetition and lack of eo-ordination, this being particularly noticeable in the treatment of four-layer devices. This, however, is to be expected in a composite work such as this, and workers in this increasingly important aspect of switching will be grateful to the editor for collecting the existing relevant material together in one volume.

E. M. DeELEY

\section{VIBRATIONS IN TWO- DIMENSIONAL SYSTEMS}

Chladni Figures

A Study in Symmetry. By Mary Désirée Waller. Pp. xxii +163 (47 plates). (London: G. Bell and Sons, Ltd., 1961.) 42s. net.

R. MARY D. WALLER devoted a large part of her scientific life to the study of the vibrations two-dimensional systems-a subject usually associated with the name of Chladni, whose work dates back to the eighteenth century. It is sad to reflect that she died at the end of 1959 when she had com. pleted the writing of this book and had already made arrangements for its publication. As one who knew her personally and was familiar with much of her work, I find it a pleasure and indeed a privilege to review such an exceptional book now that it has been published. The final publication was greatly facilitated by the assistance of her intimate friends and coworkers, Miss Bertha Turner and Miss Winifred A. Leyshon.

The beautiful experiments described in the book are the outcome of years of patient and fascinating work in which Chladni's early observations on vibrating plates have been systematically repeated and much extended. As an example of Mary Waller's great integrity, charm and kindliness, to which Prof. Andrade refers in his foreword to the book, it may be not inappropriate to quote from her 'acknowledy. ments': "I am indebted in a unique way to the unknown vendor of ice-creams who set me on my way in the laboratory, while he, refusing to give me his name, wandered away into the London streets to pursue his way, in what was in 1932 a precarious way of earning a livelihood". It was to this chance meeting that she was led to the discovery of the solid carbon dioxide method of producing Chladni figures-the icecream vendor had asked her why his bicycle bell gave out a clattoring ring when he touched it with 'dry-ice'. He provided her with a piece of the solid 